Teologia i Moralność, volumen 16(2021), numer 1(29)

doi: 10.14746/TIM.2021.29.1.7

ORCID: 0000-0003-4678-726X

\author{
ANDRZEJ DERDZIUK \\ Katolicki Uniwersytet Lubelski Jana Pawła II \\ Wydział Teologii
}

\title{
O adekwatną teologię moralną na nasze czasy
}

Powyższe zagadnienie może być pojęte i omawiane na dwa sposoby. Pierwszą płaszczyzną możliwych rozważań jest postawienie diagnozy aktualnego stanu teologii i zarazem stanu społeczeństwa, do którego teolog jest posłany. Drugą płaszczyzną refleksji jest wskazanie postulatów, które teologia winna spełnić, aby skutecznie podjąć dialog ze światem w XXI wieku. Istotnym elementem rozważań jest też właściwe zidentyfikowanie adresatów teologii, co przyczynia się do formułowania bardziej adekwatnego przesłania.

\section{Uwarunkowania uprawiania teologii}

Obecnie można mówić o rozbudowanej strukturze systemu nauczania teologii w Polsce, który obejmuje 12 ośrodków akademickich zatrudniających wielu nauczycieli akademickich. Do tego trzeba dodać liczne seminaria diecezjalne i zakonne, które dysponują własną kadrą. Liczba nie przekłada się na jakość i mamy do czynienia z rozdrobnieniem kadry teologicznej. Niektóre wydziały cierpią na brak studentów i to też wpływa na współczesną sytuację teologii moralnej, o której można stwierdzić, że znajduje się w stanie kryzysu. $\mathrm{Z}$ powodu mniejszej liczby kandydatów na studia teologiczne zarówno świeckich, jak i duchownych, zmniejsza się liczba kadry nauczającej zdolnej do tworzenia dzieł z tego zakresu. Trudniej też wyłowić zdolnych studentów, którzy by kontynuowali poszukiwania naukowe, bo jest ich mniej i przełożeni kościelni nie chcą ich poświęcić nauce, gdyż czekają na nich różne inne zadania w Kościele. Gdy nie będzie się inwestować w kadrę naukową Kościoła, 
w przyszłości może to grozić pojawieniem się zjawiska antyintelektualizmu oraz utraty zdolności apologetycznych.

Najbardziej istotnym problemem jest jednak coraz mniej głęboka wiara, która mogłaby nadawać siłę podejmowanym decyzjom mężnego dawania świadectwa o Bogu w zsekularyzowanym świecie. Obecnie bowiem sposób oddziaływania uczniów Chrystusa polega na tym, że stają się oni znakiem sprzeciwu. Stąd też opór ze strony świata nie jest czymś przedziwnym, ale zwyczajną formą reakcji zranionego grzechem starego człowieka na orędzie Ewangelii, które chce go wytrącić z wygodnego życia i popchnąć w kierunku przekraczania siebie oraz zachęcić do motywowanego miłością pragnienia złożenia daru ze swego życia.

W świetle przesłania Ewangelii narzekanie na opór świata, który jest wrogi uczniom Chrystusa, nie usprawiedliwia postawy bierności i wycofywania się, ale raczej obnaża stan ducha chrześcijan, którzy stracili gorliwość w dzieleniu się Dobrą Nowiną. Owa bierność ujawnia się także w niepodejmowaniu tematów niewygodnych i trudnych, by nie narazić się na ostracyzm środowiska akademickiego. Mając na uwadze zachętę św. Ignacego Antiocheńskiego, który swego ucznia św. Polikarpa zachęcał, by był jak uderzone kowadło (Pius XII 2013, 1455), trzeba zwrócić uwagę na coraz mniejszą odporność chrześcijan na stres wynikającą z nieumiejętności przyjmowania wyzwań nieżyczliwego świata. Jest to spowodowane spłaszczeniem perspektywy ludzkiego życia do doczesności i odrzuceniem eschatologicznego wymiaru ludzkiej egzystencji. Jeśli bowiem tylko w tym życiu pokładamy nadzieję (por. 1 Kor $15,19)$, to nie tylko tracimy zapał apostolski ożywiany pragnieniem uratowania od potępienia niezliczonych rzesz ludzkich, ale też sami przywiązujemy się do komfortu ludzkiej pielgrzymki przez ziemię, nie dbając o cel wiecznej szczęśliwości, do której zmierzamy.

Odrzucanie przyjmowania perspektywy zbawienia i osiągnięcia szczęścia wiecznego albo potępienia i pójścia do piekła sprawia, że w ludzkim życiu mniejsze znaczenie mają sprawy ostateczne, a w związku z tym nie motywują one ziemskich wyborów. Lęk o to, jak dalece można narazić się światu, przysłania perspektywę stawania przed sądem Bożym i osłabia gotowość znoszenia niewygody ziemskiej podróży w nadziei osiągnięcia celu w postaci zbawienia. Tego problemu dotknął św. Jan Paweł II w rozmowie z Vittoriem Messorim, gdy stwierdził: „Człowiek się zgubił, kaznodzieje się zgubili, katecheci się zgubili, wychowawcy się zgubili. Nie mają już odwagi «straszyć piekłem». Może nawet słuchacze przestali się go lękać. To prawda, że człowiek dzisiejszej cywilizacji jest w jakiś sposób niewrażliwy na «sprawy ostateczne». [...] Na rzecz takiej niewrażliwości działa to wszystko, co się nazywa sekularyzacją i sekularyzmem, z konsekwentną postawą konsumpcyjną, nastawioną na używanie dóbr tego świata" (Jan Paweł II 1994, 138-139). 
Skutkiem spłaszczenia perspektywy eschatologicznej jest także zjawisko, które papież Franciszek nazwał dekonstrukcjonizmem polegającym na utracie zmysłu historycznego. Stąd ludzka wolność próbuje dziś wszystko budować od zera i odrzuca jakiekolwiek pouczenie płynące z przeszłości, uznając je za nieaktualne i anachroniczne. W takiej sytuacji człowiek koncentruje się na nieokiełznanej potrzebie konsumpcji bez ograniczeń i akcentowaniu rozmaitych form indywidualizmu bez treści (Franciszek 2020a, 13). W klimacie postmodernistycznego kryzysu prawdy i przeroście indywidualizmu przekazywane przez teologię wskazania w zakresie życia moralnego są traktowane jako niepotrzebne i ograniczające nieskrępowaną ekspresję zachcianek, gdyż człowiek sam arbitralnie określa swoje postępowanie, nie dbając o ujmowanie go $\mathrm{w}$ aspekcie obiektywnie pojmowanego dobra i zła.

Przemiany społeczno-kulturowe spowodowały zmianę mentalności, w której nie mieszczą się pytania o wieczność oraz nie ma miejsca na odnoszenie postępowania osoby do norm moralnych. Przypisywanie sumieniu indywidualnemu prerogatywy najwyższej instancji osądu moralnego, która bez odniesienia do obiektywnej prawdy w sposób kategoryczny i odrzucający sprzeciw decyduje o tym, co jest dobre, a co złe, doprowadziło do sytuacji, że do twierdzenia o nieomylności własnego sumienia „,dodano tezę, wedle której osąd moralny jest prawdziwy na mocy samego faktu, że pochodzi z sumienia. Wskutek tego zanikł jednak nieodzowny wymóg prawdy, ustępując miejsca kryterium szczerości, autentyczności, «zgody z samym sobą», co doprowadziło do skrajnie subiektywistycznej interpretacji osądu moralnego" (Jan Paweł II 1993, 32).

W sytuacji zanikania kultury nasyconej wartościami chrześcijańskimi, coraz trudniej jest odnaleźć się katolikom, których nazywa się dzisiaj kulturowymi, to znaczy, że ich wiara jest umotywowana określonymi wartościami zakorzenionymi w kulturze, ale nie jest oparta na osobowej i osobistej więzi z Chrystusem pogłębionej intelektualnie i potwierdzonej postępowaniem wypływającym $\mathrm{z}$ wiary. Można w tym kontekście przytoczyć słowa papieża Benedykta wypowiedziane w 2011 roku w Erfurcie: „Kiedy w pierwszej fazie nieobecności Boga Jego światło nadal jeszcze rzuca poświatę i utrzymuje w całości ład ludzkiego istnienia, wydaje się, że bez Boga jest to także możliwe. Ale im bardziej świat oddala się od Boga, tym wyraźniej widać, że człowiek coraz bardziej «traci» życie w nadużywaniu władzy, w pustce serca, w pożądaniu przyjemności i szczęścia” (Benedykt XVI 2011a). Sama kultura nie wystarczy do ustrzeżenia wartości, gdy traci ona swój fundament, odrzucając odniesienie do Boga.

W tej sytuacji teologowie moraliści muszą sobie zdać sprawę, że nie da się zawrócić czasu i nie odbuduje się tkanki kulturowej ożywiającej społeczeństwa minionego okresu. Nie możemy wpadać w anachronizm i bronić war- 
tości, które są zakorzenione w kulturze i mają charakter temporalny. Papież Benedykt wypowiedział się na ten temat we Fryburgu Bryzgowijskim: „Nie chodzi tu o znalezienie nowej taktyki, aby na nowo zapewnić Kościołowi znaczenie. Chodzi przede wszystkim o zaniechanie tego wszystkiego, co jest jedynie taktyką, i o poszukiwanie pełnej rzetelności, która nie lekceważy ani nie thumi niczego z prawdy naszego dziś, ale realizuje w pełni wiarę dzisiaj, przeżywając ją właśnie całkowicie w prostocie dnia dzisiejszego, prowadząc ją ku pełnej tożsamości, usuwając z niej to, co tylko na pozór jest wiarą, a w rzeczywistości jedynie konwencją i przyzwyczajeniami” (Benedykt XVI 2011b).

Istotnym wyzwaniem stojącym przed teologią w Polsce jest jasne wskazywanie rozstrzygnięć sytuacji moralnych, które pojawiają się w życiu społecznym. Udzielanie adekwatnych i pogłębionych odpowiedzi na dylematy moralne jest ważne w sytuacji, gdy pojawiają się samozwańcze autorytety, które uzurpują sobie prawo do pouczania innych. Mając świadomość głębokiej polaryzacji politycznej i kulturowej Polaków, łatwo o przyklejenie komuś łatki przedstawiciela określonej partii, który wypowiada się według wskazań dominującej ideologii. Wzywanie do pojednania i zajmowanie stanowiska pojednawczego wobec obu stron sporu powoduje narażanie się wszystkim, co znalazło swój wyraz w nazywaniu takich osób symetrystami. Nie jest jednak dobrą rzeczą zachowywanie lękliwego milczenia i brak prezentowania klarownej postawy ewangelicznej, gdyż prowadzi to do zapełnienia przestrzeni publicznej argumentami, które są sprzeczne z duchem chrześcijaństwa.

Brak słyszalnego głosu teologów został zauważony przez Cezarego Kościelniaka, który w ramach dyskusji na forum Klubu Jagiellońskiego stwierdził: „Wreszcie w sytuacji bierności polskich biskupów i intelektualnej śpiączki polskich szkół teologicznych to robota poza oficjalnym obiegiem kościelnym, głównie dla świeckich i to niekoniecznie teologów. Powinnością czasu nie jest tylko ochrona pomników, lecz wypalenie własnej cegły w międzypokoleniowej budowli katedry ducha" (Kościelniak 2020). W tym kontekście warto przypomnieć wezwanie papieża Franciszka, który w konstytucji Veritatis gaudium wymaga, by wykładowca, któremu powierza się zajęcia akademickie, ,wyróżniał się głęboką wiedzą, świadectwem życia chrześcijańskiego i kościelnego oraz poczuciem odpowiedzialności” (Franciszek 2017, cz. I, art. $25, \S 1)$.

\section{Adresaci teologii moralnej}

Zadaniem teologów jest odróżnienie tego, co zmienne, od tego, co jest niezmienne i niezbywalne. Wartości fundamentalne mogą jednak zupełnie inaczej ujawniać się w naszych czasach i dotrą do człowieka tylko na miarę jego zdol- 
ności percepcyjnych, które są uwarunkowane kulturą, w której żyje. Ewangelizacja kultury nie oznacza odrzucania form ekspresji dylematów egzystencjalnych tylko dlatego, że nie pasują do wcześniejszych schematów. Człowieka trzeba zbawiać tam, gdzie on jest, gdyż nie da się na siłę wprowadzać go do rzeczywistości, której on nie rozumie i której nie jest w stanie przyjąć. Warto zaakceptować uwagę papieża Franciszka, że życie jest bogatsze od teorii zapisanych w książkach i pielęgnowanych w ideografii kultury, w której żyjemy.

Słowa papieża z adhortacji Evangelii gaudium brzmią dla teologów moralistów jak ostrzeżenie: „Rzeczywistość przewyższa ideę. Zakłada to unikanie różnych form zasłaniania rzeczywistości: angelicznych puryzmów, totalitaryzmów relatywizacji, deklaratystycznych nominalizmów, projektów bardziej formalnych niż realnych, antyhistorycznych fundamentalizmów, intelektualizmów pozbawionych mądrości. Funkcją idei - opracowania konceptualnego - jest uchwycenie, zrozumienie rzeczywistości i kierowanie nią. Oderwana od rzeczywistości idea rodzi odrealnione idealizmy i nominalizmy, które jedynie starają się ją klasyfikować i definiować, ale jej nie kształtują. To, co angażuje i pociąga, to rzeczywistość oświecona rozumowaniem. Trzeba przejść od formalnego nominalizmu do harmonijnej obiektywności. Na różne sposoby manipuluje się prawdą, podobnie jak gimnastykę zastępuje się kosmetyką. Są politycy - a także przywódcy religijni - którzy pytają, dlaczego lud ich nie rozumie i nie idzie za nimi, skoro ich propozycje są tak logiczne i jasne. Prawdopodobnie dzieje się tak dlatego, że usadowili się w królestwie czystych idei i sprowadzili politykę lub wiarę do retoryki. Inni zapomnieli o prostocie i ściągnęli z zewnątrz obcą i niezrozumiałą dla ludzi racjonalność" (Franciszek 2013, 231-232).

Zadaniem teologii moralnej jest wskazywanie Ludowi Bożemu dróg realizacji powołania do doskonałości w miłości (Derdziuk 2010, 201). W tym celu, opierając się w głębszym stopniu na Piśmie Świętym, winna nawiązywać dialog ze współczesnym światem i wsłuchiwać się w to, co Duch mówi do Kościoła przez znaki czasu. Zakłada to zdolność słuchania zarówno Boga, jak i ludzi współczesnych, których radość i nadzieje oraz smutek i trwoga winny być uważnie rozeznawane przez teologów moralistów (Franciszek 2020, 56). Misja profetyczna nie polega tylko na wskazywaniu nowych dróg rozwoju moralności w świecie, ale nade wszystko na funkcji hermeneutycznej, w której podaje się autorytatywną interpretację zjawisk w kluczu Bożej historii zbawienia. Teolog moralista winien zatem osobiście dbać o większą bliskość Boga, która pomoże mu wyczulić się na działanie Ducha Bożego w Kościele. Paradoksalnie sprawdzianem wierności Ewangelii jest postawa lepszego rozumienia ducha świata, w którym teolog, krytycznie patrząc na świat oczyma Jezusa, staje się świadkiem odwiecznej mądrości.

Głoszenie orędzia moralnego Ewangelii winno być skierowane do wszystkich ludzi. Jednak zależnie od tego, do kogo bezpośrednio się kieruje teolog 
moralista, zmienia się zakres treści, które on podejmuje, oraz język i sposób argumentowania użyty do skłonienia adresata, by przyjął on przekazywane treści. Można zasadniczo wskazać następujące grupy odbiorców współczesnych dyskusji artykułów i podręczników teologii moralnej. Od dawna wyszła ona bowiem z niszy eklezjalnej ograniczającej się do kandydatów do kapłaństwa, którzy byli jedynymi studentami teologii. Zastępy świeckich to nie tylko świeccy teologowie, ale też zwykli wierni Kościoła katolickiego, którzy mają prawo być karmieni treściami teologicznymi ożywiającymi i ugruntowującymi ich wiarę. Wskazuje na to dekret soborowy nakazujący: „Szczególną troskę należy skierować ku udoskonaleniu teologii moralnej, której naukowy wykład karmiony w większej mierze nauką Pisma Świętego niech ukazuje wzniosłość powołania wiernych w Chrystusie i ich obowiązek przynoszenia owocu w miłości za życie świata" (Sobór Watykański II 2012,16). Często różny poziom ogólnej wiedzy humanistycznej, jak i stopień utożsamiania się z moralnym przesłaniem Kościoła istotnie różnicuje sposób przekazu treści teologicznomoralnych. Stąd też teolog moralista winien znać problemy, którymi żyją zwykli ludzie, i używać języka adekwatnego do poziomu percepcji odbiorców, by wskazywać im wzniosłość powołania chrześcijańskiego.

Ważnym odbiorcą twórczości teologów moralistów są środowiska różnych komisji etycznych i bioetycznych, które działają w wielu instytucjach jako odpowiedź na wymagania ustawowe oraz pragnienie zapewnienia standardów etycznych w działalności medycznej, biznesowej i medialnej. Eksperci teologiczni biorący udział w komisjach podejmują dialog na płaszczyźnie humanistycznej, próbując znaleźć wspólny język z kolegami i koleżankami, którzy często są niewierzący i nie uznają argumentów konfesyjnych płynących z objawienia (Góralczyk 2007, 191). Zresztą podobny sposób argumentacji podejmują dokumenty watykańskich kongregacji kierowane do ludzi dobrej woli, które opierają się na racjonalnym dowodzeniu stwierdzeń moralnych Kościoła, korzystając z wiedzy naukowej i prawa naturalnego.

W przypadku ekspertów pracujących w komisjach skupiających osoby niewierzące pojawia się tendencja do zawężania spektrum swoich zainteresowań do poszukiwania konsensusu z inaczej myślącymi. Nie zawsze przyjmuje to postać kompromisu, ale w istotny sposób oddala od radykalizmu Ewangelii i milcząco pomija wpływ łaski. Ma to poważne konsekwencje dla uprawianej przez nich teologii, zarówno w jej zakresie treściowym, jak i w postawie wobec Kościoła. Teologia moralna jako eklezjalna nauka wiary opiera się na świadectwie Jezusa, który nie tylko przyniósł instrukcje na temat ludzkiego postępowania w zakresie moralności, ale nade wszystko odnowił stworzenie, udzielając mu zbawczej łaski zdolnej wynieść człowieka na wyższy poziom postępowania cechującego się dążeniem do doskonałej miłości mającej źródło w Bogu. 
Obserwując zjawisko dialogu teologii ze światem, dostrzega się trudną do pokonania aporię, ujawniającą się w karkołomnej próbie pogodzenia racji odzwierciedlających mentalność świata i mądrość Ewangelii. W istocie owa aporia teoretycznie nie istnieje, gdyż Jezus przyszedł zbawić każdego człowieka, takim jakim on faktycznie jest. Stąd mądrość Ewangelii jest ponadczasowa i uniwersalna. Chodzi o właściwe zrozumienie zawartości Dobrej Nowiny i przekazanie jej słuchaczom na poziomie ich historycznych uwarunkowań.

Pozostaje jednak problem adekwatnego języka, który ujmuje bogactwo Ewangelii oraz jest zrozumiały dla ludzi uwikłanych w uwarunkowania kulturowe i moralne. Prawda Ewangelii jest nade wszystko Dobrą Nowiną, ale może stać się oskarżeniem w obliczu braku zgodności życia jej adresatów z sumieniem wskazującym prawdę o zachowaniu.

Papież Franciszek, przemawiając 21 czerwca 2019 roku na kongresie teologów zatytułowanym Teologia po Veritatis gaudium, powiedział: „Teologia, zwłaszcza w takim kontekście, winna być teologią akceptacji i rozwijać autentyczny dialog z instytucjami społecznymi i obywatelskimi, z ośrodkami uniwersyteckimi i badawczymi, ze zwierzchnikami religijnymi i ze wszystkimi ludźmi dobrej woli, w celu budowania w pokoju społeczeństwa integrującego i braterskiego, a także w celu ochrony świata stworzonego. Kiedy we wstępie Veritatis gaudium wymienia się pogłębianie kerygmatu i dialog jako kryteria odnowy studiów, chodzi o powiedzenie, że mają one służyć drodze Kościoła, który coraz bardziej stawia w centrum ewangelizację. Nie apologetykę, nie podręczniki - jak słyszeliśmy - lecz ewangelizowanie. W centrum jest ewangelizacja, co nie oznacza prozelityzmu. W dialogu z kulturami i religiami Kościół głosi Dobrą Nowinę o Jezusie i praktykę miłości ewangelicznej, którą On głosił jako syntezę całego nauczania Prawa, wizji proroków i woli Ojca. Dialog jest przede wszystkim metodą rozeznania i głoszenia Słowa miłości, które jest skierowane do każdego człowieka i które chce zamieszkać w sercu każdej osoby. Tylko gdy słucha się tego Słowa i doświadcza miłości, którą ono przekazuje, można rozpoznać aktualność kerygmatu. Dialog w ten sposób rozumiany jest formą akceptacji” (Franciszek 2020b).

Różnorodność środowisk, do których posłany jest teolog, wskazuje na potrzebę zróżnicowania środków przekazywania Dobrej Nowiny. Ludzie dzisiaj coraz rzadziej czytają podręczniki, a częściej szukają odpowiedzi na swe pytania w Internecie. Potrzebują raczej krótkich tekstów, które w jasny i przystępny sposób ukażą prawdy ewangeliczne jako coś, co może ożywiać ludzkie życie i nadawać jemu sens. Warto wspomnieć w tym kontekście dwóch wybitnych polskich teologów moralistów, którzy prowadząc systematyczne badania i tworząc naukowe dzieła z zakresu teologii moralnej, potrafili je przekazywać prostym językiem tysiącom odbiorców. Ksiądz prof. Janusz Nagórny (1950-2006) znany był jako bardzo dobry kaznodzieja i autor felietonów, które 
naświetlały kwestie moralności chrześcijańskiej oraz podejmowały aktualne zagadnienia nurtujące katolików (Derdziuk 2008, 15-35). Ksiądz prof. Ireneusz Mroczkowski (1949-2020) dzięki swojemu zaangażowaniu we wspólnoty ludzi świeckich oraz prowadzeniu bloga potrafił inspirować do szukania odpowiedzi na pytanie, jak po chrześcijańsku ująć aktualne wyzwania czasu (Zadykowicz 2020a, 117-145; Derdziuk 2020, 23-33). Do teologów o mniejszym zakresie oddziaływania należy postać ks. prof. Alojzego Drożdża (1950-2019), który w wielu artykułach na łamach Tarnowskiego Gościa Niedzielnego naświetlał różne aspekty chrześcijańskiej moralności (Surmiak 2020, 46-56). Aktualnie taką posługę hermeneutyczną pełni ks. prof. Paweł Bortkiewicz, który pisze wiele tekstów i udziela się w różnych mediach.

\section{Misja teologa moralisty}

Do istotnych zadań teologia moralisty, w poważny sposób zajmującego się uprawianiem teologii moralnej jako życiowego powołania, należy osobiste uświęcenie się, które jest owocem wejścia w nowe przymierze z Bogiem w ramach odkrywania swej misji w Kościele. Przez osobistą świętość teolog nie tylko oddaje chwałę Bogu, ale też daje czytelne świadectwo, że rozważane przez niego treści mają moc przemiany życia i otwierają na działanie Ducha Świętego. Instrukcja o powołaniu teologa wskazuje na to jednoznacznie: „Teo$\log$ - z racji swojego powołania - musi żyć intensywną wiarą i zawsze łączyć badania naukowe z modlitwą. [...] Uprawianie teologii wymaga duchowego wysiłku związanego ze zdobywaniem ścisłości i uświęceniem" (Kongregacja Nauki Wiary 1995, 356).

Można też odwołać się do słów papieża Benedykta XVI z listu na 100-lecie urodzin św. Jana Pawła, w którym papież senior stwierdził, że jego poprzednikowi z Polski ,przez całe życie chodziło o to, aby obiektywne centrum wiary chrześcijańskiej - naukę o zbawieniu - subiektywnie przyjąć za swoje i uzdalniać innych do jego przyjęcia” (Benedykt XVI 2020). Przykładem owocności misji teologa jest postać św. Alfonsa Marii de Liguori, który więcej zdziałał przykładem życia oddanego Bogu promieniującego pobożnością niż podręcznikami, które napisał.

Kolejnym zadaniem teologa jest służba Kościołowi objawiająca się w dostarczaniu Urzędowi Nauczycielskiemu Kościoła nowych inspiracji do odpowiadania na wyzwania świata oraz pogłębiania intuicji teologicznych przez ulepszanie rozumienia orędzia moralnego i dostarczanie argumentów do uzasadnienia nadziei, którą niesie przesłanie ewangeliczne. W tej samej linii służenia Kościołowi jest bycie krytycznym głosem wobec instytucji Kościoła, któremu konstruktywna krytyka jest potrzebna do owocnego spełniania misji 
ogłaszania światu zbawienia. Teolog winien wypełniać misję prorocką przez pogłębianie nauki głoszonej w Kościele i ukazywanie konsekwencji przyjmowanych założeń oraz używanych terminów. Zarazem winien być zdolny do interpretowania znaków czasu, dostrzegając to, co Duch mówi do Kościoła. Oznacza to gotowość do słuchania ludzi i poznawania aktualnych trendów kulturowych, które zostaną zinterpretowane w świetle antropologii teologicznomoralnej.

Ksiądz Tadeusz Zadykowicz, odwołując się do encykliki Veritatis splendor (Jan Paweł II 1993, 110), napisał, że zadaniem teologów moralistów ,jest uczestnictwo w munus propheticum Chrystusa i Kościoła, głoszenie przykazań Bożych i miłości Chrystusa, pouczanie o normach, które Kościół ogłasza, poszukiwanie głębszych rozumowych uzasadnień do jego nauczania, przekonywanie o słuszności jego nakazów oraz ich znaczeniu, naświetlanie podstaw biblijnych, znaczeń etycznych oraz motywacji antropologicznych doktryny moralnej Kościoła, dostarczanie ludziom nowej argumentacji do wierzenia i postępowania zgodnego z wiarą (Zadykowicz 2020b, 367-368).

Instrukcja o powołaniu teologa przyznaje, że „Pasterze nie zawsze natychmiast rozumieli wszystkie aspekty lub całą złożoność pewnych zagadnień” (Kongregacja Nauki Wiary 1995, 361). W misji teologa „Gotowość do lojalnej akceptacji tego nauczania, głoszonego przez Urząd Nauczycielski w materii, która sama w sobie może podlegać udoskonaleniom, powinno stanowić regułę. Może się jednak zdarzyć, że w pewnych przypadkach teolog będzie miał wątpliwości stawiające pod znakiem zapytania stosowność, formę czy nawet treść danego wystąpienia Urzędu Nauczycielskiego" (Kongregacja Nauki Wiary 1995, 361).

Zadaniem teologów jest też tworzenie gremiów opiniotwórczych, które nie tylko będą brały udział w bieżącej debacie publicystycznej, ale wypracują odpowiedź na wyzwania czasu ukazującą wartość rozwiązań istniejących w przeszłości i zachowującą otwartość na nowe sposoby rozumienia problemów kwestii moralnych i ich adekwatnego przedstawiania człowiekowi zanurzonemu w zsekularyzowanej kulturze nasyconej konsumizmem, pogonią za sukcesem oraz poddanej procesowi cyfryzacji i globalizacji. Teolog musi sobie zdawać sprawę, że proces przemian kulturowych ciągle przyśpiesza i zmiany w mentalności wpływającej na rozumienie podstawowych wartości są bardzo głębokie, tak iż obecnie ma się do czynienia z zupełnie nową wrażliwością.

Chodzi też o tworzenie środowisk żywego Kościoła, w których teologia karmi duchowość i pobożność wiernych Kościoła mających świadomość dokonujących się zmian i zarazem mających zdolność do ich interioryzowania w codziennej egzystencji (Nagórny 2006, 115). Teolog pomaga w znalezieniu odpowiedzi na pytanie, jak żyć i jak reagować na wyzwania czasów. Teologia tworzona zza biurka nie ożywi Kościoła i nie udzieli odpowiedzi na pytania, 
które stawiają ludzie w świecie. Brak wyczucia sytuacji współczesnego człowieka sprawia, że treści przekazywane przez publikowane teksty nie trafiają do ludzi, którzy nie rozumieją ich znaczenia i nie potrafią ich odnieść do swojego życia. Potrzeba zatem, jak przypomina to papież Franciszek, nawrócenia duszpasterskiego teologii, która nic nie tracąc ze swej pogłębionej refleksji opartej na poprawnej metodologii i solidnej wiedzy zbieranej w uważnej lekturze, będzie umiała dostrzec perspektywę eklezjalną i potrafi ożywiać wiarę Ludu Bożego.

\section{AN ADEQUATE MORAL THEOLOGY FOR OUR TIMES}

\section{SUMMARY}

The present state of moral theology in Poland bears some signs of a crisis, as the number of students of theological sciences is shrinking and the faith, which can give wings to the testimony of theologians, is weakening. The progressive process of secularization becomes at the same time a challenge to a deeper interpretation of contemporary culture and to find a new way and language of conveying the Gospel content. Pope Francis emphasized that theological studies "constitute a kind of providential cultural laboratory in which the Church performs a performative interpretation of the reality that flows from the event of Jesus Christ and which is nourished by the gifts of wisdom and knowledge which the Holy Spirit enriches in various forms the whole people of God." Proper identification of the addressees of the Church's moral message will allow for a better adjustment of the forms of teaching. Theology is to serve the People of God in a deeper experience of faith and to contribute to the ongoing public debate in order to explain the Church's position and to argue moral truths. For this purpose, you also need to use new media that will allow you to reach a wider audience.

Keywords: moral theology, methodology of moral theology, vocation of theologian

Słowa kluczowe: teologia moralna, metodologia teologii moralnej, powołanie teologa

\section{BIBLIOGRAFIA}

Benedykt XVI. 2011a. Kazanie podczas nabożeństwa ekumenicznego w bylym klasztorze augustiańskim, Erfurt, 23 września 2011.

Benedykt XVI. 2011b. Przemówienie wygłoszone w czasie spotkania z niemieckimi katolikami świeckimi zaangażowanymi w życie kościelne i społeczne, Fryburg Bryzgowijski, 25 września. 
Benedykt XVI. 2020. List z okazji setnej rocznicy urodzin papieża Polaka. Dostęp 16.10.2020. https://pl.aleteia.org/2020/05/15/benedykt-xvi-ujawnia-jak-2-razy-powiedzial-nie-janowipawlowi-ii-list-papieza-seniora/.

Derdziuk, Andrzej. 2008. Ksiądz Janusz Nagórny świadek teologii nadziei. W: Świadek nadziei. Ks. prof. Janusz Nagórny twórca i nauczyciel teologii moralnej, red. Andrzej Derdziuk, 15-35. Lublin: Wydawnictwo Diecezjalne w Sandomierzu.

Derdziuk, Andrzej. 2010. Teologia moralna w stużbie wiary Kościoła. Lublin: Wydawnictwo KUL.

Derdziuk, Andrzej. 2020. Życiorys naukowy ks. Ireneusza Mroczkowskiego. W: Dyscyplina rozumu i uczciwość serca. Ks. Ireneusza Mroczkowskiego (1949-2020) sposób uprawiania teologii moralnej, red. Andrzej Derdziuk, Wojciech Kućko, 23-33. Lublin: TN KUL.

Franciszek. 2013. Adhortacja apostolska Evangelii gaudium.

Franciszek. 2017. Konstytucja apostolska Veritatis gaudium.

Franciszek. 2020a. Encyklika Fratelli tutti.

Franciszek. 2020b. Przemówienie na kongresie nt. "Teologia po Veritatis gaudium» w Neapolu. Dostęp 16.10.2020. https://opoka.org.pl/biblioteka/W/WP/franciszek_i/-przemowienia/neapol_ 21062019.html.

Góralczyk, Paweł. 2007. Teologia moralna - w poszukiwaniu tożsamości metodologicznej. Studia Nauk Teologicznych, 2, 189-202.

Jan Paweł II. 1993. Encyklika Veritatis splendor.

Jan Paweł II. 1994. Przekroczyć próg nadziei. Lublin: RW KUL.

Kongregacja Nauki Wiary. 1995. Instrukcja o powołaniu teologa w Kościele „Donum veritatis”. W: W trosce o petnię wiary. Dokumenty Kongregacji Nauki Wiary 1966-1994, thum. i opr. Zygmunt Zimowski i Janusz Królikowski, 353-369. Tarnów: Biblos.

Kościelniak, Cezary. 2020. Aktywny Kościół odpowiedzia na ulicznych hejterow. Zmieńmy front tej wojny. Katolickie imaginarium. Dostęp: 16.10.2020. https://klubjagiellonski.pl/2020/08/17/.

Nagórny, Janusz. 2006. Natura teologii moralnej. W: Polska teologia moralna czterdzieści lat po Soborze Watykańskim II, red. Janusz Nagórny i Jerzy Gocko, 91-125. Lublin: Gaudium.

Pius XII. 2013. Z listu apostolskiego papieża. W: Liturgia godzin zakonów franciszkańskich w Polsce, t. II. Okres Wielkiego Postu, Okres Wielkanocy, 1455. Wrocław: Franciszkańskie Wydawnictwo św. Antoniego.

Sobór Watykański II. 2012. Dekret o formacji kapłańskiej „, Optatam totius”.

Surmiak, Wojciech. 2020. „Pod etoskopem” ks. prof. Alojzego Drożdża na łamach „Tarnowskiego Gościa Niedzielnego” (1996-2004). Wykaz bibliograficzny. W: Człowiek Bogu. Człowiek człowiekowi. Człowiek światu. Ksiegga pamiatkowa dedykowana śp. Ks. prof. dr hab. Alojzemu Drożdżowi (1950-2019), red. Wojciech Surmiak, 46-56. Katowice: Księgarnia św. Jacka.

Zadykowicz, Tadeusz. 2020a. Ks. Ireneusz Mroczkowski - Autor bloga. W: Dyscyplina rozumu i uczciwość serca. Ks. Ireneusza Mroczkowskiego (1949-2020) sposób uprawiania teologii moralnej, red. Andrzej Derdziuk i Wojciech Kućko, 117-145. Lublin: TN KUL.

Zadykowicz, Tadeusz. 2020b. Czy jesteśmy moralistami kolejnego przełomu?. W: Człowiek Bogu. Człowiek człowiekowi. Człowiek światu. Księga pamiątkowa dedykowana śp. Ks. prof. dr hab. Alojzemu Drożdżowi (1950-2019), red. Wojciech Surmiak, 367-368. Katowice: Księgarnia św. Jacka.

Andrzej Derdziuk OFMCap - profesor nauk teologicznych, specjalista teologii moralnej, kierownik Katedry Bioetyki Teologicznej w Instytucie Nauk Teologicznych Katolickiego Uniwersytetu Lubelskiego Jana Pawła II, ORCID: 0000-00034678-726X, kontakt: andrzej.derdziuk@kul.pl 